\title{
Correspondence
}

\section{HLA antigens in ankylosing spondylitis with peripheral arthritis}

SIR, We were much interested in the article by Sanmarti et al on HLA studies involving patients with ankylosing spondylitis and peripheral arthritis reported in the Annals. ${ }^{1}$ We noted some parallels with our own findings of an HLA-DR7 association with peripheral arthritis in a similar population. ${ }^{2}$ Especially noteworthy was the use of an HLA-B27 control population in both studies, an essential step in this instance because of the strong negative linkage disequilibrium between HLA-DR7 and HLA-B27. In Sanmarti's study the HLA-DR7 association was limited to children with an erosive peripheral arthritis in addition to ankylosing spondilitis. Although we did not ascertain the extent of erosive disease in all our patients. they were biased towards those with more severe disease and hence were also likely to be erosive. The inclusion of patients that had already had joint replacement helps support this conclusion. Another similarity was the occurrence of patients with childhood onset disease in both studies. Five of 25 patients from Spain had an onset below the age of 17 , whereas none of the group with ankylosing spondylitis only did so, though the mean age of both groups was approximately the same.

In neither study is it possible to separate the earlier age of onset from the presence of peripheral arthritis so that HLA-DR7 may well act as a gene determining severity of disease and thus explain both sets of observations.

Rheumatic Disease Unit.

University of Alberta,

Edmonton and Children's Hospital

Medical Center.

Cincinnati, Ohio

\section{References}

1 Sanmartí R, Ercilla M G. Brancós M A. Cid M C. Collado A. Rotés-Querol J. HLA class II antigens (DR. DQ loci) and peripheral arthritis in ankylosing spondylitis. Ann Rheum Dis 1987: 46: 497-500.

2 Aaron S. Miller M L. Howard J, et al. Complementation with HLA-A and HLA-D locus alleles in ankylosing spondylitis with peripheral arthritis. J Rheumatol 1985; 12: 553-7.

\section{Isolated HLA-B27 cross reactive group (CREG) associated Achilles tendinitis}

SIR, We read with interest the article by Olivieri et al, which describes a case of isolated HLA-B27 associated Achilles tendinitis. ${ }^{1}$ The authors suggest that Achilles tendinitis may for a long time be the only feature of the HLA-B27 associated disease process. We have recently observed a patient with longstanding HLA-B7 associated bilateral Achilles tendinitis without seronegative spondarthropathy.

A 35 year old man who suffered for two years and six months from recurrent bilateral Achilles tendinitis presented to us in November 1987. There was no history of low back pain, peripheral arthritis, ocular complaint, urethritis, diarrhoea, cutaneous involvement, or physical injury. A detailed general physical examination showed only soft tissue swelling, warmth, and tenderness along the Achilles tendon and at its calcaneal insertion. The blood counts, chemistry, serological tests, and urine analysis were normal; the erythrocyte sedimentation rate was 36 $\mathrm{mm} / \mathrm{h}$. HLA typing was positive for the B7 antigen. Radiographs of the heels showed posterior calcaneal erosions. Chest, sacroiliac, lumbar, dorsal, and cervical spine $x$ rays were normal. Treatment was started with diclofenac $150 \mathrm{mg} / \mathrm{day}$, and the condition improved.

Our case supports the hypothesis proposed by Olivieri $e t$ al and extends the spectrum of disease to HLA-B27 CREG (cross reactive group) ${ }^{2}$ positive patients.

Department of Rheumatology,

J M NOLLA SOLE*

Hospital de Bellvitge

'Princeps d'Espanya',

University of Barcelona.

L’Hospitalet, Barcelona,

Spain

*Correspondence to $\operatorname{Dr}$ J M Nolla Solé, Department of Rheumatology, Hospital de Bellvitge 'Princeps d'Espanya', C/Feixa Llarga s/n, 08907 L'Hospitalet de Llobregat, Barcelona, Spain.

\section{References}

1 Olivieri I, Gemignani G, Gherardi S, Grassi L, Ciompi M L. Isolated HLA-B27 associated Achilles tendinitis. Ann Rheum Dis 1987; 46: 626-7.

2 Haberhauer G. Intérêt pratique du typage HLA en rhumatologie. EULAR Bull 1987: 2: 46-50. 


\section{ARD}

\section{Isolated HLA-B27 cross reactive group (CREG) associated Achilles tendinitis.}

J M Nolla Solé, X Juanola Roura, J Valverde Garcia, et al.

Ann Rheum Dis 1988 47: 615

doi: 10.1136/ard.47.7.615-b

Updated information and services can be found at:

http://ard.bmj.com/content/47/7/615.2.citation

These include:

Email alerting Receive free email alerts when new articles cite service this article. Sign up in the box at the top right corner of the online article.

Notes

To request permissions go to:

http://group.bmj.com/group/rights-licensing/permissions

To order reprints go to:

http://journals.bmj.com/cgi/reprintform

To subscribe to BMJ go to:

http://group.bmj.com/subscribe/ 